\title{
Profiles of oestradiol-17 $\beta$ and progesterone and follicular development during the reproductive season in mink (Mustela vison)
}

\author{
G. Lagerkvist ${ }^{1}$, E. J. Einarsson ${ }^{2}$, M. Forsberg ${ }^{3}$ and H. Gustafsson ${ }^{4}$ \\ ${ }^{1}$ Department of Animal Breeding and Genetics, Swedish University of Agricultural Sciences, \\ Funbo-Lövsta Research Station, S-755 97 Uppsala, Sweden; ${ }^{2}$ Norwegian Poultry Breeders \\ Association, P. B. N-1430 Aas, Norway; ${ }^{3}$ Department of Clinical Chemistry, Swedish University of \\ Agricultural Sciences, Box 7038, S-750 07 Uppsala, Sweden; and ${ }^{4}$ Department of Obstetrics and \\ Gynaecology, Swedish University of Agricultural Sciences, Box 7039, S-750 07 Uppsala, Sweden
}

\begin{abstract}
Summary. Plasma concentrations of oestradiol-17 $\beta$ and progesterone were studied in yearling mink females. The blood samples were collected from 2 March until 13 April in females not subjected to mating and in females mated on two consecutive days, early or late in the breeding season, or with 8-9 days between matings. Peaks in oestradiol$17 \beta$ were recorded on the day of first mating, in relation to the second wave of growing follicles, and in early April, around the time when implantation should have occurred. Significant rises in progesterone were recorded from 17 to 21 March and were slightly later in females mated late in the season.

Histological studies of ovaries from unmated females revealed that the number of 'active' follicles exceeded the number of degenerated or luteinized follicles until 7 April, after which the number of degenerated follicles increased rapidly. Degeneration was followed by luteinization. On 15 April, ovaries were collected from two females having 15 luteinized follicles each. These females had increased plasma concentrations of progesterone.

These studies indicate that, in female mink, peaks in oestradiol-17 $\beta$ coincide with the first mating as a result of the copulatory act and that unmated females appear to experience a luteal phase in the absence of ovulation.
\end{abstract}

Keywords: oestradiol; progesterone; reproduction; mink; ovary; steroids

\section{Introduction}

The reproductive cycle of mink is annual and the breeding season is short, extending from late February to the end of March in the Northern Hemisphere. Ovulation is induced by the copulatory act and occurs 33-72 $\mathrm{h}$ after mating (Hansson, 1947; Enders, 1952; Venge, 1959). The ova pass through the oviduct, where they are fertilized, and reach the uterus 8-9 days post coitum. At this point (early blastocyst stage) they normally enter a resting period (Hansson, 1947) that lasts until $\sim 49$ days (post coitum) (Enders, 1952). The corpora lutea are active during pregnancy, secreting progesterone (Venge, 1959; Enders \& Enders, 1963; Møller, 1973), but initially only small amounts (Canivenc \& Bonnin-Laffargue, 1967). The low concentration of progesterone allows a second oestrus and the ovulation of a new set of ova if the female is remated after 7-8 days. Occasionally, a third ovulation may be induced after another 7-8 days. Hansson (1947) showed that the most common mating intervals were 1-2 days and 7-10 days, concluding that the high frequency of mating intervals of 7-10 days indicated that the oestrous cycle was $\sim 8-9$ days long. This agreed with the earlier suggestion by Enders (1940) that female mink undergo waves of 
follicular maturity during the mating season. The theory that female mink have three to four spontaneous heat periods was generally accepted and practical mating schedules were developed accordingly. A common commercial breeding strategy has been to mate females early in the breeding season and remate them after 7 or 8 days or, if females are not receptive until later in the season, remate them on the following day (referred to as $1+7,1+8$ and $1+1$ systems, respectively). Ova fertilized after the last ovulation seem to develop more frequently than ova from previous ovulations (Enders, 1949). The first set of ova are partly expelled after a second mating (Adams, 1981 ); $\sim 85 \%$ of the kits born originate from the last ovulation (Johansson \& Venge, 1951).

Elofson et al. (1989) showed that unmated female mink do not undergo spontaneous heat periods at cyclic intervals; but that when she is ready to mate she is receptive any time during the mating period. Thus, to maximize reproductive output, yearling females should be mated early in the breeding season and remated in order to induce two ovulations, whereas older females should be mated during the latter part of March to induce one ovulation. The positive effects of late mating on litter size seemed attributable to an increased number of ova ovulated and a lower mortality rate of the blastocysts before implantation, because of the shorter gestation period.

Implantation occurs from the end of March to the beginning of April, and gestation periods between 38 and 74 days have been observed (Hansson, 1947; Enders, 1952; Einarsson, 1987). Implantation is controlled by photoperiod, activating the corpora lutea via hypophyseal prolactin (Papke et al., 1980; Martinet et al., 1981; Murphy et al., 1981). The concentration of plasma progesterone begins to rise around the vernal equinox (Allais \& Martinet, 1978; Pilbeam et al., 1979; Martinet et al., 1983). Einarsson (1985) found that plasma progesterone increased to $>10 \mathrm{ng} / \mathrm{ml}$ 31.6 days before parturition and that the day of mating affected the day of increase. Møller (1973) showed that progesterone started to rise $\sim 40$ days before parturition or 7-10 days before implantation, and reached maximal concentrations 15-30 days before parturition.

Few studies have been conducted on oestrogen profiles in mink. Pilbeam et al. (1979) investigated the variation in plasma oestradiol- $17 \beta$ in female mink over 1 year. The highest concentrations were observed during pro-oestrus (January-February), but during oestrus they declined. They decreased further after mating and remained low throughout pregnancy and lactation. In contrast, Tauson et al. (1988) reported increasing concentrations during the period 25 February to 8 March.

In females not subjected to mating, little is known about follicular development or hormone profiles during the breeding season. Elofson et al. (1989) examined ovaries from such females killed on various dates during 12 March to 2 April. The ovaries mainly contained follicles characterized as active. Only occasionally were single atretic or luteinized follicles observed. In a few cases, luteinized follicles were accompanied by a rise in concentration of plasma progesterone, but, since only one ovary per female was serially sectioned, no definite conclusions could be drawn.

In the present investigation we studied (a) profiles of plasma oestradiol-17 $\beta$ and progesterone during the mating season and early gestation, in unmated females and in females mated according to different breeding schedules, to investigate how hormone profiles were affected by breeding schedule and mating date; (b) follicular development in unmated females during the latter part of the breeding season and during the subsequent period; and (c) number of ova, embryos and corpora lutea in six females mated according to different breeding schedules.

\section{Materials and Methods}

\section{Experiment 1}

The practical part of the project was carried out in 1986, at the Experimental Fur Farm of the Agricultural University of Norway, Aas. The aim was to investigate how hormone profiles were affected by breeding schedule and mating date. As an extension of the experiments by Elofson et al. (1989), ova and embryos were collected and corpora lutea counted in females mated according to different strategies. Thirty yearling females of standard type, free from plasmacytosis, were kept under conventional farming conditions. 
The matings were set for 6 and 7 March (group A), 6 and 14 March (group B) and 17 and 18 March (group C). Each group comprised 10 females. If the female was not receptive, she was tried again on the following day. Only four females in group A and two in group B accepted mating on $6 \mathrm{March}$; thus, 8 March became the average first mating date in these groups (range 6-9 March). In groups A and B, four and two females, respectively, did not accept remating; the latter two were then transferred to group A. In group C, all females accepted mating on 17 March, except one. which mated on the following day; two did not remate.

From 7 March to 9 April blood samples were collected from each female by clipping the tip of the claw three times a week, to determine plasma concentrations of oestradiol-17 73 and progesterone. One female from each group was killed on 7 March, 14 March and 3 April for histological studies of the ovaries. On 21 March, two females from each group were killed and the blastocysts collected and classified according to the methods described by Elofson $e t a l$. (1989). The remaining five females per group were used to extend the hormone profile until to April.

\section{Experiment 2}

The second part of the project was conducted in 1987. The objective was to compare mated and unmated females, in terms of their ovarian activity and hormone profiles. The practical work was carried out at the Research Farms of the Swedish University of Agricultural Sciences, Uppsala, and the Agricultural University of Norway, Aas. The experiment was conducted with yearling standard females free from plasmacytosis. Its design is shown in Table !.

Table 1. Date of mating, blood sampling period and date of slaughter for female mink (Expt 2)

\begin{tabular}{lclll}
\hline Group & No. females & \multicolumn{1}{c}{ Matings } & \multicolumn{1}{c}{ Blood sampling } & \multicolumn{1}{c}{ Date of slaughter } \\
\hline 1 & 5 & Not mated & 16 February to 6 March & Not slaughtered \\
2 & 10 & Not mated & 2 March to 13 April & 13 April \\
3 & 10 & $9+10$ March & 2 March to 13 April & 13 April \\
4 & 14 & Not mated & At slaughter & 25 March to 15 April \\
5 & 14 & $9+18$ March & At slaughter & 25 March to 15 April \\
\hline
\end{tabular}

In groups 1 - 3, blood was collected three times a week, by tail vein puncture, to determine plasma oestradiol-17 concentrations. In groups 4 and 5 , two females were simultaneously killed on seven occasions within the period stated. Blood was collected by heart puncture at the time of killing and analysed for plasma progesterone. In groups 2,4 and 5 , ovaries were removed immediately after killing for histological examination of ovarian activity. In group 5, first matings occurred on 9-11 March.

Blood sampling and enzyme immunoassays. Blood $(1 \mathrm{ml}$ ) was sampled in the morning, before feeding, in heparinized tubes, centrifuged at 3000 r.p.m. and stored in plastic tubes at $-20^{\circ} \mathrm{C}$ until assay.

Plasma concentrations of oestradiol-17 3 were determined by an enzyme immunoassay previously described by Jones \& Madej (1988). Serial dilutions of extracted plasma containing a high oestradiol-17ß concentration produced a dose-response curve parallel to the standard curve. The intra-assay coefficients of variation, calculated from the precision profiles of 19 assays, were $<20 \%$ in the range of $25-150 \mathrm{pmol} / 1$. The interassay coefficients of variation for quality control samples were 8.7 (at mean $27.7 \mathrm{pmol} / \mathrm{l}, n=19$ ) and $10.6 \%$ (at mean $44 \cdot 3 \mathrm{pmol} / \mathrm{l}, n=19$ ).

The direct enzyme immunoassay for progesterone was previously described and validated for use in mink (Tauson et al., 1988). The intra-assay coefficients of variation were $<15 \%$ in the range of $2.8-35 \mathrm{nmol} / 1$. The interassay coefficients of variation for quality control samples, estimated in ten assays, were 10 (at mean $19 \mathrm{nmol} / \mathrm{l})$ and $8 \%$ (at mean $42 \mathrm{nmol} / \mathrm{l}$ ).

All values represented the means of duplicate determinations. Samples were grouped and assayed by treatment and reassayed by time.

Histological studies. The ovaries were removed immediately after killing the mink, fixed in formalin, dehydrated according to standard methods and embedded in histowax at $56^{\circ} \mathrm{C}$. The ovaries were cut in sections $10 \mu \mathrm{m}$ thick. Every twentieth section was stained with haemalum eosin. Normal, atretic and luteinized follicles were identified microscopically in unmated females (groups 2 and 4 in Expt 2) and corpora lutea in mated females (two females from each group in Expt 1 and group 5 in Expt 2). The diameter of each follicle was not measured, but variations between 0.8 and $1.4 \mathrm{~mm}$ were observed. Follicles judged as active had an intact layer of columnar granulosa cells coating the basement membrane, with cell nuclei displaced towards the follicle vacuole. Follicles with degenerated granulosa cells, showing detachment from the follicular wall and nuclear pycnosis, were considered atretic.

Statistical analysis. Analyses were performed using the general linear model procedure (GLM) of SAS (SAS Institute Inc., 1985). The analyses concerning oestradiol-17 $\beta$ and progesterone concentrations were carried out according to the split-plot design model: 


$$
\mathrm{Y}_{i j k t}=\mu+\mathrm{a}_{i}+\mathrm{b}_{j}+\mathrm{c}_{i k}+(\mathrm{ab})_{i j}+\mathrm{e}_{i j k l}
$$

in which $Y_{i j k l}$ denotes each individual observation, $\mu$ is the general mean, $a_{i}$ is the fixed effect of treatment group, $b_{j}$ is the fixed effect of day of sampling, $c_{i k}$ is the random effect of female-within-treatment group, $(a b)_{i j}$ is the interaction effect between treatment group and day of sampling and $\mathrm{e}_{i j k t}$ is the random error.

Treatment group, day of sampling and their interaction were tested against female effect. When evaluating treatment effects, female-within-treatment group was used as an error term. All statistical $t$ tests between individual least-squares means having a $P$ value $<0$-05 were considered significant. Values are expressed as least-squares means \pm standard error (LS means \pm s.e.).

\section{Results}

\section{Experiment 1}

Oestradiol-17ק . The effect of treatment group was not significant in the statistical model, but there was a significant $(P<0.01)$ interaction between group and sampling day (Fig. 1a). In groups $A$ and $B$, the first samplings were excluded because of haemolysis. Therefore, no information was provided about the oestradiol concentrations around the first early mating. In all groups, concentrations increased during the second and third weeks of March and peaked on 21, 19 and 17 March, in groups A, B and C, respectively. During 21-26 March, concentrations decreased, but rose rapidly again for the early-mated groups at the beginning of April, around or just after the time when implantation usually occurs (Hansson, 1947).

Within-day differences between groups were not significant, because of high standard errors (Fig. 1a), but the difference between groups $\mathrm{A}$ and $\mathrm{C}$ was almost significant $(P<0.08)$ on the last sampling day, 9 April. Within groups, significant differences between sampling dates were found. In group A, oestradiol concentrations were higher on 4-9 April than on 10 March $(P<0.05)$ or 26 March $(P<0.01)$. In group B, the lowest concentration, on $24 \mathrm{March}$, differed significantly from the peaks on 19 March and 4 April. In group C, concentrations were significantly higher on 17 March than on the first sampling day ( $7 \mathrm{March}$ ) or $21 \mathrm{March}$, implying that mating in group $\mathrm{C}$ coincided with a surge of oestradiol. Thereafter, the concentrations rapidly declined.

Progesterone. The effect of group was highly significant in the statistical model, but differences between groups were not significant when tested within sampling day (Fig. 1b). When concentrations were tested against those obtained on the first sampling day, significant rises were noted on 21, 17 and 21 March, for groups A, B and C, respectively. The number of observations within group and sampling date varied between five and 10; the large variation between females within group and date made it difficult to obtain statistical significance. Groups A and B had concentrations of 5-7 nmol progesterone/1 on 14 March whereas concentrations in group $C$ were almost undetectable (Fig. 1b).

Histological studies and number of ova or embryos in the oviduct and uterus. Unmated females killed on 7 and 14 March had only follicles characterized as active. Of the mated females killed on $14 \mathrm{March}$, one was mated on 6 and 14 March and had nine corpora lutea. One female mated on 8 March had active follicles, but no corpora lutea, and had obviously not ovulated, possibly because of the short duration of the copulatory act $(10 \mathrm{~min})$.

In the two females killed on 21 March that had been mated twice with a 9-day interval between matings, no blastocysts were recovered from the uterus, but more corpora lutea were observed than ova or embryos recovered from the oviduct (Table 2). On average, these females had the highest ovulation rate, whereas the two females that had not accepted a second mating had the lowest, based on the number of corpora lutea. Although the sample was small, the results agreed with those reported by Elofson et al. (1989). In the females mated late in the season (group C), the number of corpora lutea was identical to the number of embryos recovered from the oviducts. 

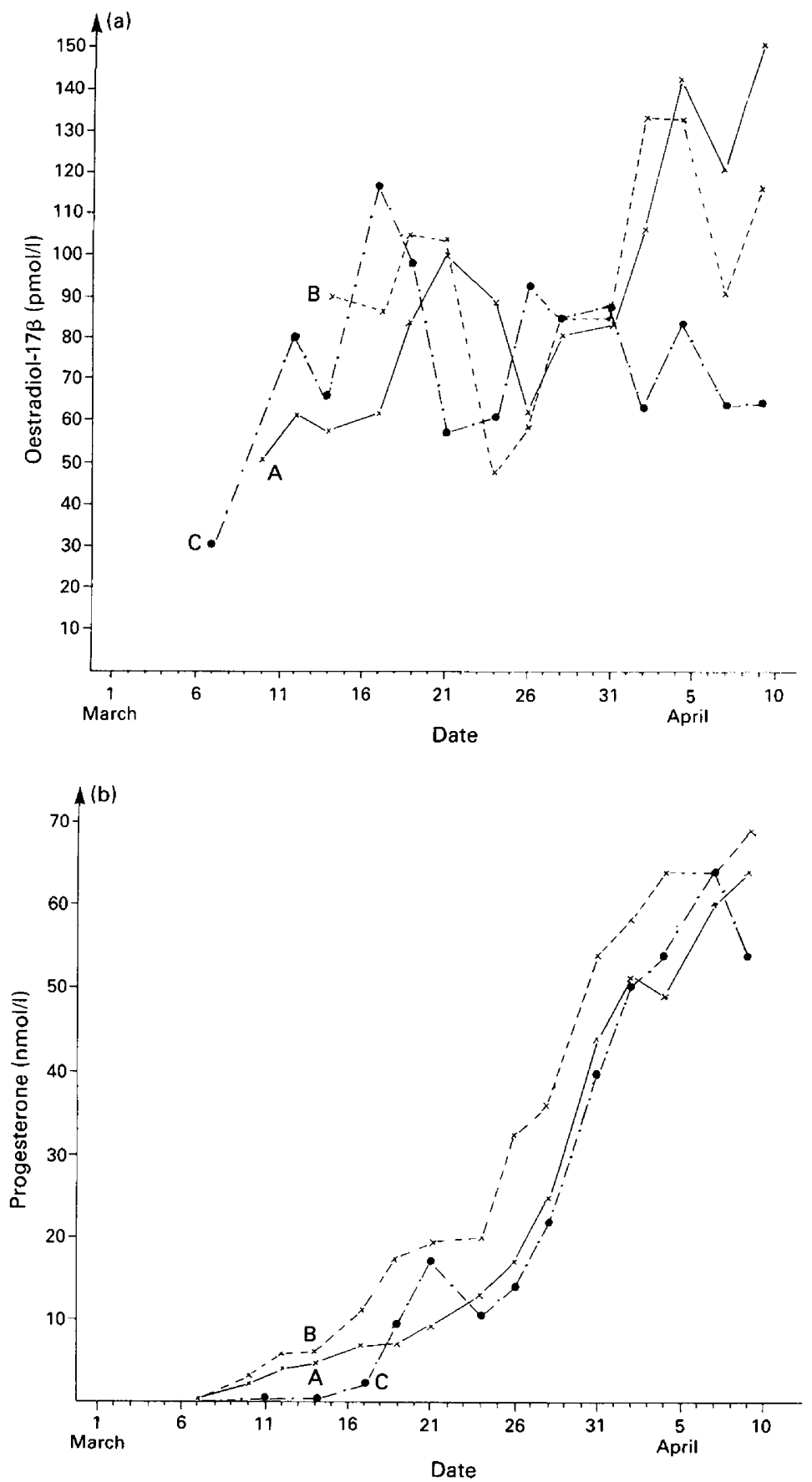

Fig. 1. Concentrations of plasma (a) oestradiol-17 $\beta$ and (b) progesterone (least squares (LS) means) in female mink mated 6-9 March, once or on two consecutive days (group A, remated after 8 days (group B, ---) or mated $17+18$ March (group C, $-\cdot-\cdot-$ ). Standard errors of the LS means depend on whether comparisons are made within (s.e. range 14-30 pmol oestradiol/l, mean $18 \mathrm{pmol} / \mathrm{l} ; 2.6-4.5 \mathrm{nmol}$ progesterone/1; mean $3.5 \mathrm{nmol} / \mathrm{l}$ ) or between groups (s.e. range $24-52 \mathrm{pmol}$ oestradiol $/ 1$, mean $32 \mathrm{pmol} / 1 ; 6 \cdot 1-10 \cdot 4 \mathrm{nmol}$ progesterone/1; mean $7 \cdot 7 \mathrm{nmol} / 1)$. 
Table 2. Number of ova or embryos in oviduct and uterus and number of corpora lutea in six female mink killed on 21 March (Expt 1)

\begin{tabular}{|c|c|c|c|c|c|c|}
\hline \multirow[b]{2}{*}{ Group } & \multirow{2}{*}{$\begin{array}{l}\text { Mating } \\
\text { dates } \\
\text { in March }\end{array}$} & \multicolumn{2}{|c|}{ Ova or embryos in oviduct } & \multicolumn{2}{|c|}{ Embryos in uterus } & \multirow{2}{*}{$\begin{array}{l}\text { No. } \\
\text { corpora } \\
\text { lutea }\end{array}$} \\
\hline & & No. & Stage (No.) & No. & Stage (No.) & \\
\hline A & $6+7$ & 10 & Unfertilized & 4 & Blastocyst & 17 \\
\hline A & 8 & - & Unfertilized & 3 & $\begin{array}{l}\text { Blastocyst (1) } \\
\text { Degenerated (2) }\end{array}$ & 5 \\
\hline B & $9+17$ & 8 & $4-8$ cell & $\ldots$ & 一 & 19 \\
\hline B & $6+14$ & 10 & $\begin{array}{l}\text { Blastocyst (9) } \\
\text { Degenerated (1) }\end{array}$ & - & - & 16 \\
\hline $\mathrm{C}$ & $17+18$ & 10 & $\begin{array}{l}2-8 \operatorname{cell}(7) \\
\text { Degenerated (3) }\end{array}$ & - & - & 10 \\
\hline C & 17 & 7 & 8 cell & - & - & 7 \\
\hline
\end{tabular}

\section{Experiment 2}

Oestradiol-17ק . Females that had not been subjected to mating (group 2) differed significantly from females mated on $9+10 \mathrm{March}$ (group 3). There was also an interaction between group and sampling date. Comparisons within sampling date did not reveal significant differences, because of high s.e. (Fig. 2). In group 3, one peak in oestradiol coincided with the mating. Females were mated early in the morning and samples with high concentrations were recorded a few hours thereafter. A second peak occurred around 18-20 March and a third peak on 8 April. When peak concentrations were compared with those on the first sampling day ( $2 \mathrm{March})$, highly significant differences were obtained. Although concentrations of oestradiol seemed to decline early in April in unmated females, this trend was not confirmed statistically.

In unmated females in which sampling was performed within 16 February to 6 March, oestradiol concentrations varied considerably. The highest concentration was noted on 18 February $(127 \pm 13 \mathrm{pmol} / \mathrm{l})$ and the lowest on 23 February $(57 \pm 17 \mathrm{pmol} / \mathrm{l})$.

Histological studies of ovaries and concentrations of progesterone. In unmated (group 4) females, the active follicles dominated in number until 7 April (Table 3), but, by this time, the number of degenerating follicles had increased markedly and luteinization had frequently started in the atretic follicles (Fig. 3). Thereafter the follicles degenerated rapidly and luteinization increased.

The unmated females (group 2) killed on 13 April had, on average, $7 \cdot 7$ active (range $0-15$ ), $7 \cdot 1$ degenerated (range 0-14) and 10.1 luteinized follicles (range 2-18). Figure 4 shows a $1.2 \mathrm{~mm}$ follicle, characterized as active, with an enclosed ovum, from one of the females. Figure 5 shows a compact luteinized follicle from one unmated female killed on 7 April. The luteinized follicles were generally smaller than corpora lutea of mated females.

\section{Discussion}

Significant peaks in oestradiol-17 $\beta$ coincided with the first mating, which has not been previously demonstrated in mink. Studies of individual profiles indicated that the peaks occurred as a result of the copulatory act. Pilbeam et al. (1979) could not observe such peaks because the sampling intervals were too long. Tauson (1988) studied the profiles of oestradiol-17 $\beta$ in relation to flushing, when a period of restricted feeding was followed by feeding ad libitum 4-5 days before mating. The peak was higher in flushed females than in females not subjected to flushing, and the peak occurred earlier (on $5 \mathrm{March}$ ) than in the present investigation, i.e. before mating. However, as sampling was only performed at weekly intervals, we cannot exclude the possibility that concentrations increased further at the time of mating. In other respects, the profiles agree well with those presented here. In contrast to the study by Pilbeam et al. (1979), decreasing concentrations of oestradiol-17 $\beta$ before 


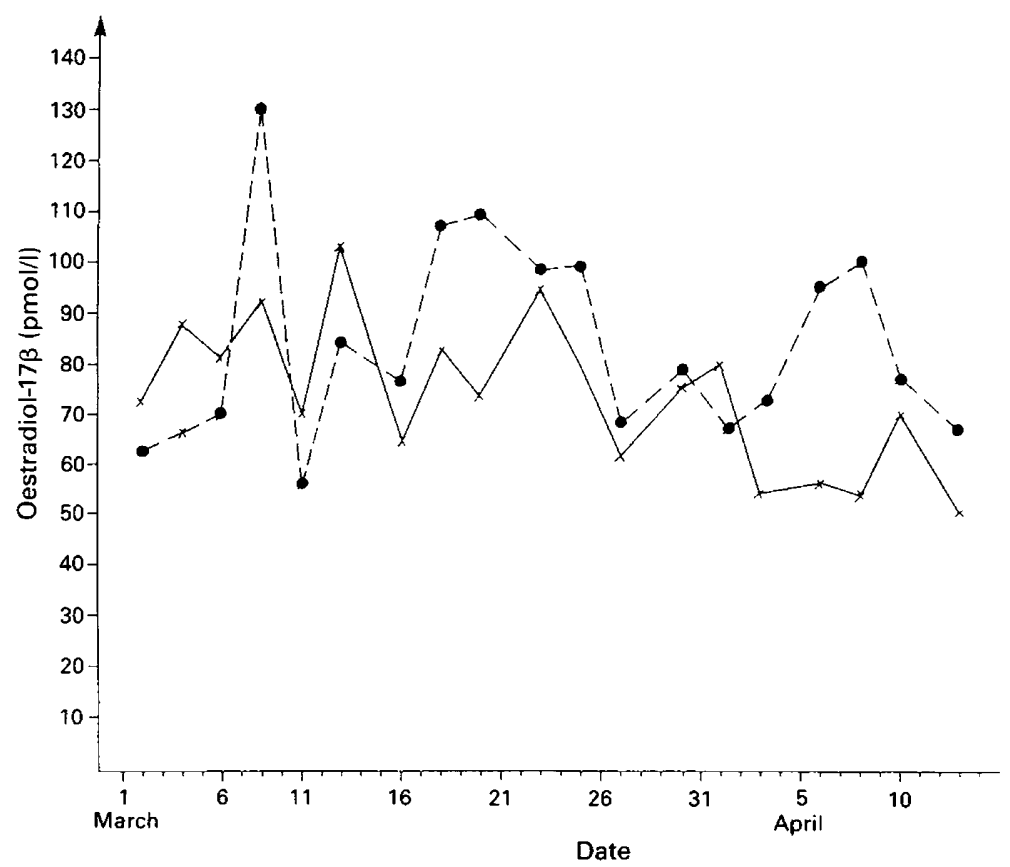

Fig. 2. Plasma concentrations of oestradiol-17 $\beta$ (least squares (LS) means) in female mink mated 9-11 March and remated after 9 days $(---)$ and in females not subjected to mating (-). Standard errors of the LS means depend on whether comparisons are made within (s.e. range $9-14 \mathrm{pmol} / \mathrm{l}$, mean $10.5 \mathrm{pmol} / \mathrm{l}$ ) or between groups (s.e. range $19-29 \mathrm{pmol} / \mathrm{l}$, mean $23 \mathrm{pmol} / \mathrm{l})$.

Table 3. Concentration of plasma progesterone and number of follicles at different stages in unmated (group 4) mink and number of corpora lutea in mated female mink (group 5); two females from each group, killed on various dates (Expt 2)

\begin{tabular}{|c|c|c|c|c|c|c|}
\hline \multirow{3}{*}{$\begin{array}{l}\text { Date of } \\
\text { slaughter }\end{array}$} & \multicolumn{4}{|c|}{ Unmated females } & \multirow{2}{*}{\multicolumn{2}{|c|}{ Mated females }} \\
\hline & \multirow{2}{*}{$\begin{array}{l}\text { Progesterone } \\
(\mathrm{nmol} / \mathrm{l})\end{array}$} & \multicolumn{3}{|c|}{ No. follicles } & & \\
\hline & & Active & Atretic & Luteinized & $\begin{array}{l}\text { Progesterone } \\
(\mathrm{nmol} / \mathrm{l})\end{array}$ & $\begin{array}{l}\text { No. corpora } \\
\text { lutea }\end{array}$ \\
\hline \multirow[t]{2}{*}{$25 \mathrm{March}$} & 0.9 & 12 & - & - & - & 18 \\
\hline & $1 \cdot 1$ & 14 & I & 3 & $40 \cdot 1$ & 16 \\
\hline \multirow[t]{2}{*}{1 April } & 0.4 & 14 & I & - & - & 22 \\
\hline & - & 11 & 3 & 2 & $>55$ & 20 \\
\hline \multirow[t]{2}{*}{3 April } & $4 \cdot 3$ & 16 & - & 4 & $46 \cdot 4$ & 16 \\
\hline & $4 \cdot 5$ & 8 & - & 5 & $>55$ & 16 \\
\hline \multirow[t]{2}{*}{7 April } & 1.6 & 24 & - & 6 & $>55$ & 13 \\
\hline & $8 \cdot 7$ & 1 & 13 & 6 & $>55$ & 18 \\
\hline \multirow[t]{2}{*}{10 April } & 1.8 & 16 & - & 4 & $>55$ & 11 \\
\hline & $9 \cdot 4$ & - & 8 & 10 & $>55$ & 19 \\
\hline \multirow[t]{2}{*}{13 April } & $4 \cdot 3$ & - & 16 & 2 & $>55$ & 14 \\
\hline & $4 \cdot 8$ & - & 15 & 12 & $>55$ & 21 \\
\hline \multirow[t]{2}{*}{15 April } & 22 & - & 9 & 15 & $>55$ & 21 \\
\hline & $>55$ & - & - & 15 & $>55$ & 21 \\
\hline
\end{tabular}




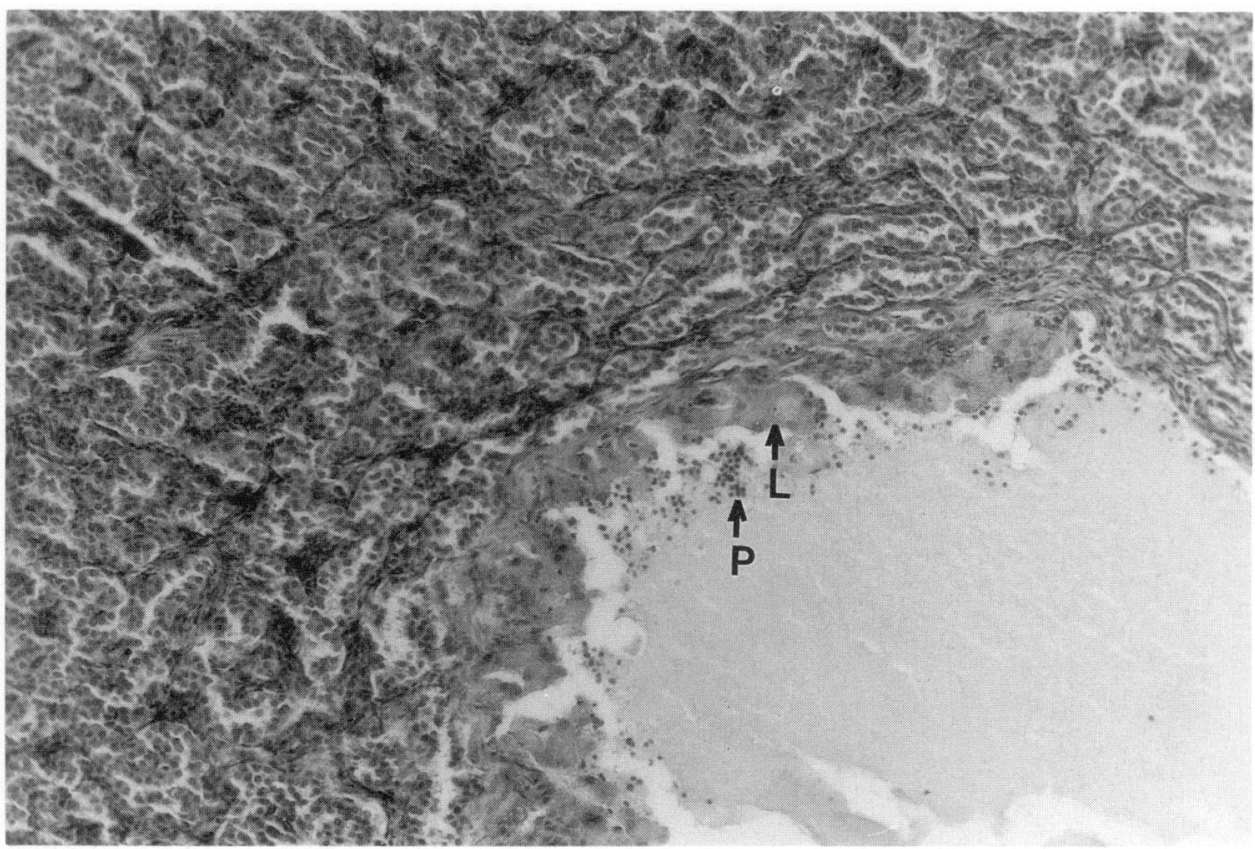

Fig. 3. Follicles characterized as atretic from unmated female mink killed 7 April (Expl 2, group 4). The female had 1 active. 8 degenerating and 10 luteinized follicles; P, pycnotic and $L$. lutcinized cells. $(\times 250)$

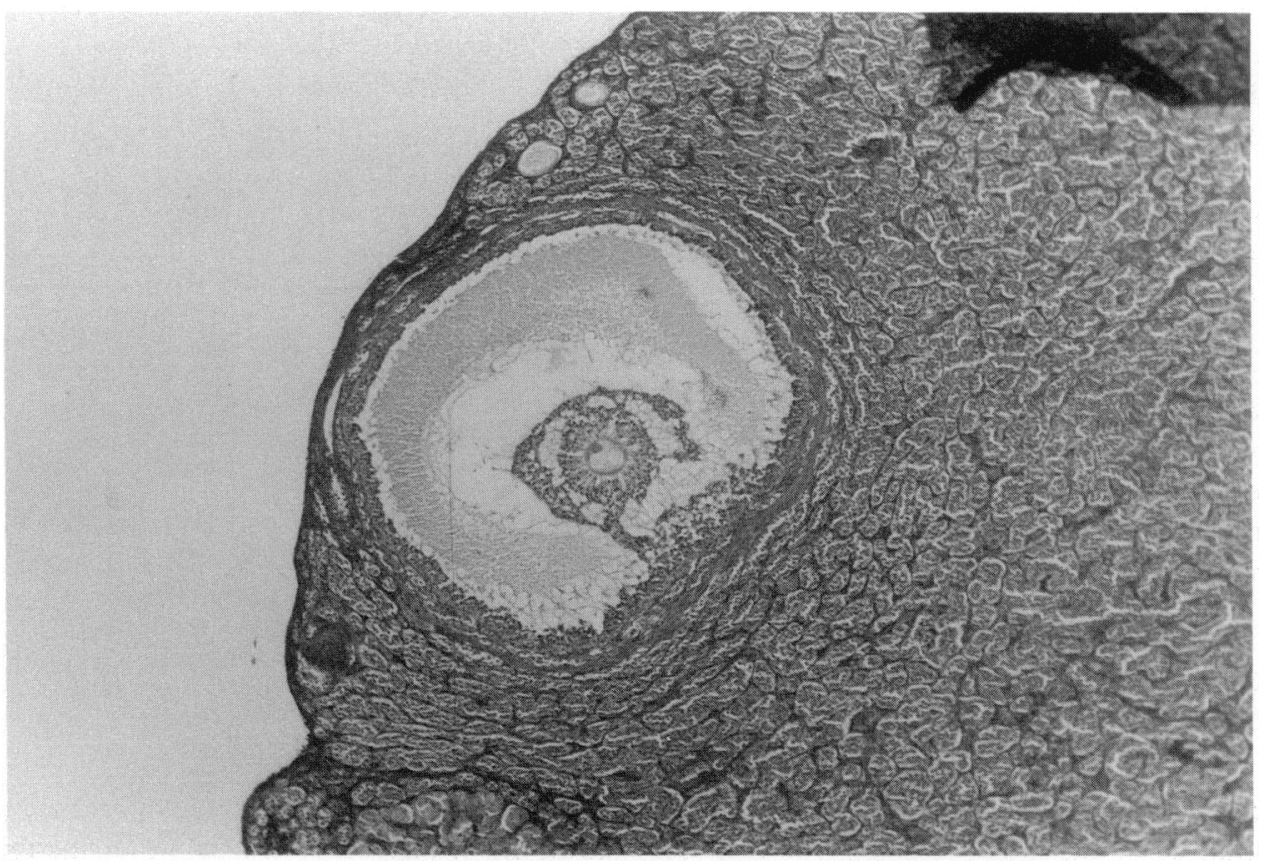

Fig. 4. Follicle characterized as active with enclosed ovum from unmated female mink (Expt 2 , group 2). The female had 9 active, 9 degenerating and 13 luteinized follicles. $(\times 50)$ 


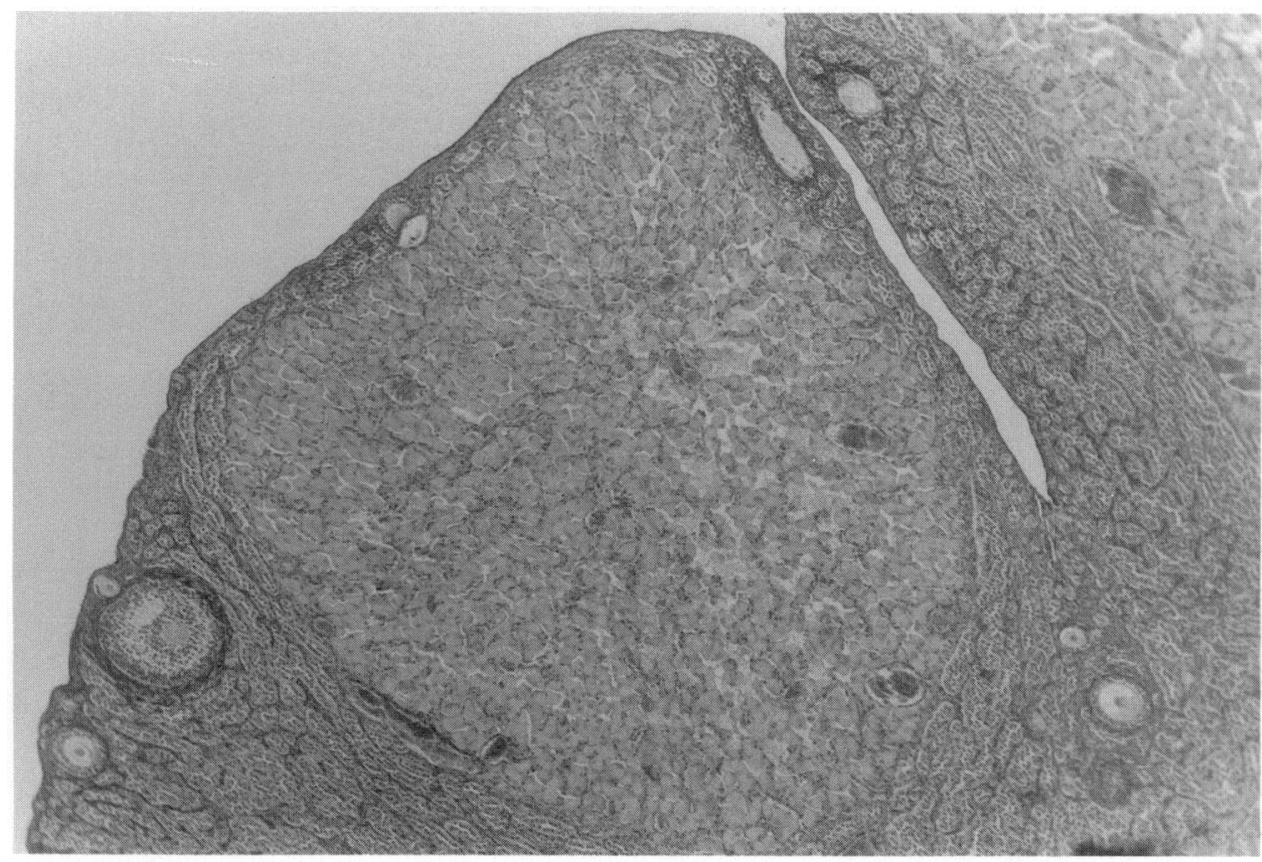

Fig. 5. Compact luteinized follicle from unmated female mink killed on 7 April (Expt 2, group 4). The female had 14 active, 1 degenerating and 3 luteinized follicles. $(\times 125)$

and during oestrus were not observed in these later investigations. Peaks in oestradiol coinciding with mating have been observed in other species exhibiting induced ovulation, such as cat (Verhage et al., 1976), llama (Sumar et al., 1988) and rabbit (Hilliard \& Eaton, 1971). Verhage et al. (1976) concluded that the surges of oestradiol were not the result of mating, although oestrous behaviour usually coincided with the surges. In llama, the increased secretion of oestradiol seemed to have been induced by mating; increased amounts were not observed in animals willing to mate, but not allowed to. In rabbits, the release of oestradiol, as measured in the ovarian effluent, peaked between 1.5 and $4 \mathrm{~h}$ after mating.

During 17-24 March, increased concentrations of oestradiol were observed in females mated carly in the season. This secretion was probably related to the second wave of growing follicles. In females mated on $17+18$ March, this second peak was delayed $\sim 1$ week and plasma concentrations were slightly lower. By this time, the corpora lutea should have been activated and producing progesterone, and females seldom accept mating, inducing a second ovulation, this late in the season.

Increased concentrations of oestradiol were observed again in early mated females during the first week of April. By this time, implantation should have been initiated or completed (Hansson, 1947). It has been shown, however, that stress caused by handling and the repeated treatment of female mink during the preimplantation period may prevent implantation (Daniel, 1971). Tauson (1988) reported an incidence of $40 \%$ barren, after frequent blood sampling in this period. Increases in oestradiol in early pregnancy in mink could be important for implantation in view of the fact that, in some species, implantation requires oestradiol in addition to progesterone (see Psychoyos, 1973; Levasseur, 1984; and Yoshinaga et al., 1969 for rats and mice; Garris, 1984 for guinea-pigs and Gadsby et al., 1980 for pigs). The high concentrations of plasma oestradiol in female mink, coinciding with or after implantation, are more likely to be of ovarian than of blastocystic origin. Stouffet et al. (1989) studied oestradiol secretion from luteal and non-luteal ovarian tissue before 
and after implantation. During the preimplantation period, the non-luteal tissue contained growing follicles and interstitial cells, but, when progesterone production had started, interstitial tissue dominated (Martinet et al., 1981). More than $70 \%$ of the total production of oestradiol originated from non-luteal tissue. The secretion of oestradiol decreased during the pre-implantation period and increased during implantation. This pattern agrees well with the plasma profiles in the present study.

The rise in progesterone came later in females that had been mated late, in agreement with the reports of Einarsson (1985) and Tauson (1988). Breeding schedule also seemed to affect the concentration of progesterone. Females mated early, to induce two ovulations ( $6+14 \mathrm{March})$, had higher concentrations than those that ovulated once (mated $6+7 \mathrm{March}$ ). The higher concentrations can be attributed to the fact that the early mated females had two sets of corpora lutea.

The histological observations of ovaries from unmated females agree with those made by Elofson et al. (1989). At the end of the breeding season, most of the follicles present were active and only a few follicles were judged as degenerated or luteinized. There were no signs of cyclicity or wave-like follicle growth as in rabbits, where follicles mature and degenerate continuously (Hill \& White, 1933). The present study further supports the theory that the active follicles persist throughout the mating season and then undergo degeneration and luteinization. The high and variable concentrations of oestradiol recorded in February may suggest early waves of follicles. We were not able to confirm whether females with luteinized follicles had ovulated. Since, however, females were not handled before killing and were kept separately from males, ovulation probably did not occur. Venge (1973) histologically examined corpora lutea from females that had been handled or in contact with a male, but not mated. In some cases, he found remains of the ova and concluded that these corpora were corpora lutea atretica. Furthermore, Venge (1973) assumed that the atretic corpora lutea produce enough progesterone to induce pseudopregnancy. Enders (1952) showed that follicles that had failed to rupture became typical corpora lutea, except for the enclosed ovum. He suggested that these might produce enough progesterone to maintain pregnancy in females with only one fetus, since one corpus luteum should not have been able to produce the required amount of progesterone. One would expect, however, that females with a single fetus would have undergone more than one ovulation. Møller (1974) found that non-ruptured follicles and luteinized follicles secreted small, but measurable, amounts of progesterone. In the present study, the two unmated females killed on 15 April had 15 luteinized follicles each, as well as increased concentrations of plasma progesterone. This implies that unmated females enter a luteal phase in the absence of ovulation.

El-Fouly et al. (1970) showed that the removal of the ovum from follicles of oestrous rabbits initiated luteinization of the granulosa cells. After 3 days, the amount of oestradiol secreted was the same as that secreted after a normal ovulation, but, after 8 days, secretion declined. Luteinization was not initiated when only the follicular fluid was removed. It is possible that the ovum secretes a substance that inhibits luteinization and that follicular atresia and luteinization are induced by the degeneration of the ovum. This could explain why single atretic or luteinized follicles can be seen in unmated female mink during the oestrous period.

Professor S. Einarsson is greatly acknowledged for his guidance in the interpretation of the histological sections.

\section{References}

Adams, C.E. (1981) Observations on the induction of ovulation and expulsion of uterine eggs in the mink, Mustela vison. J. Reprod. Fert. 63, 24I-248.

Allais, C. \& Martinet, L. (1978) Relation between daylight ratio, plasma progesterone and timing of nidation in mink (Mustela vison). J. Reprod. Fert. 54, $133-136$.

Canivenc, R. \& Bonnin-Laffargue, M. (1967) Luteal asthenia in species with delayed implantation (Meles meles, Mustela vison). Rev. Eur. Endocr. 4, 29-40. 
Daniel, J.C. (1971) Termination of pregnancy in mink by repeated injections during the period preceding implantation. J. Anim. Sci. 33, 659-661.

Einarsson, E.J. (1985) The time of increase in plasma progesterone during pregnancy in mink (Mustela vison). Theriogenology $24,75 \cdot 382$.

Einarsson, E.J. (1987) Selection for litter size in mink. III. Prepartum and preweaning observations. Norw. J. Agr. Sci. 1, 179-204.

El-Fouly, M.A., Cook, B., Nekola, M. \& Nalbandov, A.V. (1970) Role of the ovum in follicular luteinization. Endocrinology 85, 288-293.

Elofson, L., Lagerkvist, G., Gustafsson, H. \& Einarsson, S. (1989) Mating systems and reproduction in mink. Acta Agric. Scand. 39, 23-41.

Enders, R.K. (1940) A primer for mink breeders. Black Fox Magazine 23, 5 .

Enders, R.K. (1949) Multiple ovulation in mink breeding. Am. Fur Breeder 21, $6-8$.

Enders, R.K. (1952) Reproduction in the mink (Mustela vison). Proc. Am. phil. Soc. 96, 696-741.

Enders, R.K. \& Enders, A.C. (1963) Morphology of the female reproductive tract during delayed implantation in the mink. In Delayed Implantation, pp. $129 \cdot 140$. Ed. A. C. Enders. Chicago University Press, Chicago.

Gadsby, J.E., Heap, R.B. \& Burton, R.D. (1980) Oestrogen production by blastocyst and early embryonic tissue of various species. J. Reprod. Fert. 60, 409-417.

Garris, D.R. (1984) Postpartum regeneration of the guinea pig endometrium: relationship to serum estradiol and progesterone concentrations. Anat. Rec. 210, $41-44$.

Hansson, A. (1947) The physiology of reproduction in mink (Mustela vison, Schreb.) with special reference to delayed implantation. Acta Zool. 28, 1-136.

Hill, M. \& White, W.E. (1933) The growth and regression of follicles in the oestrous rabbit. J. Physiol., Lond. 80, 174-178.

Hilliard, J. \& Eaton, L.M. (1971) Estradiol-17ß, progesterone and $20 \alpha$-hydroxypregn-4-en-3-one in rabbit ovarian venous plasma. II. From mating through implantation. Endocrinology 89, 522-527.

Johansson, I. \& Venge, O. (1951) Relation of the mating interval to the occurrence of superfetation in the mink. Acta zool. Stockh. 32, 255-258.

Jones, I. \& Madej, A. (1988) A sensitive microtitre plate enzyme immunoassay of oestradiol-17 $\beta$ in the cow and mare. $J$. Immunoassay 9, 349-365.

Levasseur, M.-C. (1984) The involvement of estradiol at the time of implantation in placental mammals. Anim. Reprod. Sci. 7, 467-489.

Martinet, L., Allais, C. \& Allain, D. (1981) Role of prolactin and LH in luteal function and blastocyst growth in the mink (Mustela vison). J. Reprod. Fert. Suppl. 29, 119130.

Martinet, L., Allain, D. \& Meunier, M. (1983) Regulation in pregnant mink (Mustela vison) of plasma progesterone and prolactin concentrations and regulation of onset of the spring moult by daylight ratio and melatonin injections. Can. J. Zool. 61, 1959-1963.

Maller, O.M. (1973) The progesterone concentrations in the peripheral plasma of the mink (Mustela vison) during pregnancy. $J$. Endocr. 56, 121-132.

Meller, O.M. (1974) Plasma progesterone before and after ovariectomy in unmated and pregnant mink, Mustela vison. J. Reprod. Fert. 37, 367-372.

Murphy, B., Concannon, P.W., Travis, H.F. \& Hansel, W. (1981) Prolactin: the hypophyseal factor that terminates embryonic diapause in mink. Biol. Reprod. 25, 487-491.

Papke, R.L., Concannon, P.W., Travis, H.F. \& Hansel, W. (1980) Control of luteal function and implantation in the mink by prolactin. J. Anim. Sci. 50, 1102-1107.

Pilbeam, T.E., Concannon, P.W. \& Travis, H.F. (1979) The annual reproductive cycle of the mink (Mustela vison). J. Anim. Sci. 48, 578-584.

Psychoyos, A. (1973) Hormonal control of ovoimplantation. Vitam. Horm. 31, 201-256.

SAS Institute Inc. 1985. SAS User's Guide. SAS Institute Inc., Cary, NC, USA.

Stouffet, I., Mondain-Monval, M., Simon, P. \& Martinet, L. (1989) Patterns of plasma progesterone, androgen and oestrogen concentrations and in-vitro ovarian steroidogenesis during embryonic diapause and implantation in mink (Mustela vison). J. Reprod. Fert. 87, 209-221.

Sumar, J., Fredriksson, G., Alarcon, V., Kindahl, H. \& Edqvist, L.-E. (1988) Levels of 15-keto-13,14dihydro-PFG ${ }_{2 a}$, progesterone and oestradiol-17 $\beta$ after induced ovulations in llamas and alpacas. Acta Vet. scand. 29, 339-346.

Tauson, A.-H. (1988) Effect of flushing in plasma progesterone and plasma estradiol throughout gestation in mink. Proc. 4th Int. Sci. Congr. Fur An. Prod., Toronto 1988, pp. 31-42.

Tauson, A.-H., Gustafsson, H. \& Jones, I. (1988) Flushing of mink-effects on plasma progesterone, plasma estradiol, implantation rate and reproductive performance. Acta Agri. scand. 38, 421- 432.

Venge, O. (1959) Reproduction in the fox and mink. Anim. Br. Abstr. 27, 129-145.

Venge, O. (1973) Reproduction in the mink. Royal Veterinary and Agriculiural University, Copenhagen, Yearbook 1973, pp. 95-146.

Verhage, H.G., Beamer, N.B. \& Brenner, R.M. (1976) Plasma levels of estradiol and progesterone in the cat during polyestrus, pregnancy and pseudopregnancy. Biol. Reprod. 14, 579-585.

Yoshinaga, K., Hawkins, R.A. \& Stocker, J.F. (1969) Estrogen secretion by the rat ovary in vivo during the estrous cycle and pregnancy. Endocrinology 85, $103-112$.

Received 15 August 1990 